\title{
Development of an Enzyme Sensor Utilizing a Novel Fructosyl Amine Oxidase from a Marine Yeast
}

\author{
Wakako TsUGAWA, Fumimasa ISHIMURA, Kinuko OGAWA, and Koji SODE*
}

\begin{abstract}
Department of Biotechnology, Tokyo University of Agriculture and Technology (2-24-16 Naka-machi, Koganei-shi, Tokyo 184-8588, Japan)
\end{abstract}

Received May 1, 2000 ; Accepted July 25, 2000

\begin{abstract}
Novel enzyme sensors for fructosyl-valine, a model compound of glycated hemoglobin (HbA1c) were constructed using a newly isolated fructosyl-amine oxidase from a marine yeast Pichia sp. N1-1 strain. Both the mediator-type enzyme sensor using carbon paste electrode and the hydrogen peroxide sensor based enzyme electrode exhibit good linear correlations between 0.2 to $2.7 \mathrm{mM}$ and $0.05 \mathrm{mM}$ to $1.8 \mathrm{mM}$, respectively.
\end{abstract}

Key Words : Enzyme Sensor, Glycated Hemoglobin, Fructosyl Amine, Fructosyl Amine Oxidase

\section{Introduction}

Recently, the population of the diabetes patients are increasing significantly in Japan. It is estimated at more than 13 million, $10 \%$ of whole Japanese population. Therefore, the diagnosis of diabetes in the early stage is important. It is also important for the diabetes patient to control their blood glucose at a normal level to avoid the serious complication of developed diabetes.

Blood glucose has been utilized as the most important clinical marker for diabetes. The glycated hemoglobin (HbAlc) is considered as a representative glycemic control marker and a useful diagnostic marker. ${ }^{1)} \mathrm{HbAlc}$ is a kind of hemoglobin of which $\mathrm{N}$-terminal valine of betasubunit is non-enzymatically glycated by blood glucose. ${ }^{2}$ ) A nonenzymatic reaction of the free amino groups with glucose, resulting from the formation of a Schiff base, the aldimine, followed by the Amadori rearrangement, consequently formed a ketoamine, so-called Amadori products. $^{3}$ 'Since the life time of hemoglobin in blood is about 2-3 months, the ratio of glycated hemoglobin indicates the past 2-3 months blood glucose concentration. ${ }^{4,5)}$ Ion exchange chromatography ${ }^{6,7)}$ and immuno assay methods ${ }^{8)}$ are commonly utilized for determination of HbA1c. But enzyme sensor for HbAlc has not yet been reported.

Beside, the Amadori products consisted of free amino

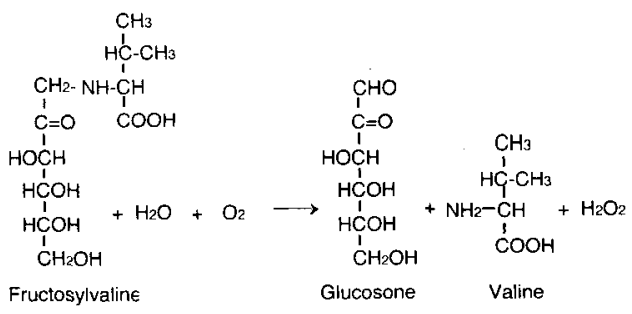

Fig. 1 Enzymatic oxidation of fructosyl-valine by fructosyl amine oxidase. acid and glucose are commonly called fructosyl-amine. A known group of enzymes, which recognizes and oxidatively degrades fructosyl-amine compounds, called fructosyl-amine oxidases (FAOs) or Amadoriases. ${ }^{9-14)}$ We recently reported the isolation of a novel FAO from marine yeast. ${ }^{15)}$

Fructosyl-valine is considered to be a model compound for HbAlc because two fructosyl-valine molecules can be released by protease digestion of one $\mathrm{HbAlc}$ molecule from its N-terminus of beta-subunits. FAOs which react with fructosyl-valine must be a good HbAlc enzyme sensor components.

This paper is the first report on fructosyl-valine enzyme sensor.

\section{1 Preparation of FAO}

\section{Experimental}

Pichia sp. strain N1-1 was cultivated aerobically at $30^{\circ} \mathrm{C}$ for 3 days in $3 \mathrm{~L}$ of culture medium $\left(\mathrm{KH}_{2} \mathrm{PO}_{4} 9 \mathrm{~g}\right.$, $\mathrm{Na}_{2} \mathrm{HPO}_{4} 18 \mathrm{~g}$, glucose $60 \mathrm{~g}, \mathrm{NaCl} 1.5 \mathrm{~g}, \mathrm{CaCl}_{2} 0.2 \mathrm{mM}$ and $\mathrm{MgSO}_{4} 2 \mathrm{mM}$ ). A $64 \mathrm{~mL}$ of autoclaved solution containing $50 \%$ glucose and $20 \%$ valine was added as nitrogen source. Cells were then centrifuged, washed twice with a $3 \% \mathrm{NaCl}$ solution, and re-suspended in a $10 \mathrm{mM}$ potassium phosphate buffer $\mathrm{pH} 7.0$ and disrupted by zymolyase $^{\mathrm{TM}}$ (ICN pharmaceuticals Inc.) followed by ultrasonication with glass beads. The homogenate was ultracentrifuged at $69800 \mathrm{x} \mathrm{g}$ for 90 minutes. The supernatant was dialyzed against a $10 \mathrm{mM}$ potassium phosphate buffer of $\mathrm{pH} 7.0$ at $4^{\circ} \mathrm{C}$ for 12 hours (crude FAO). The dialyzed sample was subjected to anion exchange chromatography (DEAE-Toyopearl $650 \mathrm{M}$, Tosoh, Tokyo, Japan), equilibrated with a $10 \mathrm{mM}$ potassium phosphate buffer of $\mathrm{pH}$ 7.0. The active fraction eluted under a linear $\mathrm{NaCl}$ gradient ( 0 to $0.75 \mathrm{M}$ ) was pooled and concentrated by lyophilization (partially-purified FAO).

\section{2 Mediator-type enzyme electrode}

Lyophilized crude FAO was mixed with $20 \mathrm{mg}$ of car- 
bon paste and packed firmly into the electrode cavity (3 $\mathrm{mm} \phi$, Bioanalytical Systems Co., Ltd.). The carbon paste (Bioanalytical Systems Co., Ltd.) electrode was incubated in the $10 \mathrm{mM}$ pottasium phosphate buffer $(\mathrm{pH}$ 7.0) containing $1 \%$ glutaraldehyde for 30 minutes for the surface crosslinking followerd by incubating in $20 \mathrm{mM}$ lysine solution for 20 minutes. The carbon paste working electrode was inserted in $10 \mathrm{~mL}$ phosphate bufferd saline containing $1 \mathrm{mM}$ methoxy phenazine methosulfate (mPMS) (Wako pure chemicals Co., Ltd.) under stirring $250 \mathrm{rpm}$ at $25^{\circ} \mathrm{C}$ with $\mathrm{Pt}$ counter electrode. The potential applied (HA-151, Hokuto Denko Co. Ltd.) was $150 \mathrm{mV}$ vs $\mathrm{Ag} / \mathrm{AgCl}$ (Bioanalytical Systems Co., Ltd.). After a steady-state current was observed, fructosyl-valine solution was added.

2. 3 Hydrogen peroxide sensor based enzyme electrode

Partially-purified FAO ( 0.05 units) was mixed with 120 $\mathrm{mg}$ of polyvinyl alcohol-stylbazole, quarternized (PVASbQ) (SPP, Toyo Gosei Co., Ltd.) solution and casted, dried and photo cross-linked by fluorescent lamp for 2 hours to make the FAO membrane. FAO membrane was then set onto the platinum electrode $(3 \mathrm{~mm} \phi)$ and covered with niron mesh. The FAO working electrode was inserted in $10 \mathrm{~mL}$ of $100 \mathrm{mM}$ potassium phosphate buffer (pH 7.0) under stirring $250 \mathrm{rpm}$ at $25^{\circ} \mathrm{C}$ with $\mathrm{Pt}$ counter electrode. The potential applied was $600 \mathrm{mV}$ vs. $\mathrm{Ag} / \mathrm{AgCl}$. After a steady-state current was observed, fructosyl-valine solution was added.

\section{Results and discussion}

A novel fructosyl amine oxidase (FAO) isolated from a fructosyl-valine assimilating marine yeast, Pichia sp. N1-1 strain catalyzes the oxidative cleavage of fructosyl-amine consuming oxygen and liberates hydrogen peroxide (Fig. 1). The optimum temperature for reaction is $30-45^{\circ} \mathrm{C}$ and $\mathrm{pH}$ optimum is 7 to 7.5 . It retains more than $80 \%$ of initial activity after ten minutes of incubation at $40^{\circ} \mathrm{C}$. This enzyme reacts well with variety of fructosyl-amines including $\varepsilon$-fructosyl-lysine, fructosyl-alanine, fructosylvaline, and fructosyl-phenylalanine but not react with glucose nor valine.

This enzyme also reacts with substrates utilizing artificial electron mediators as the electron acceptors, such as phenazine methosulfate. We constructed two types of enzyme sensors using this novel FAO based on these principles.

Figure 2 shows the calibration curve for the mediatortype enzyme sensor using carbon paste electrode. When a small amount of fructosyl-valine $(100 \mu \mathrm{L})$ was successively added to the buffer solution, the current measured at $150 \mathrm{mV}$ vs. $\mathrm{Ag} / \mathrm{AgCl}$ due to the re-oxidation of reduced electron mediator, m-PMS, was increased stepwise. A steady state current attained within 12 minutes after each addition of fructosyl-valine. The calibration curve shows the linear correlation from $0.2 \mathrm{mM}$ to $2.7 \mathrm{mM}$ of fructosyl-valine. The sensitivity of the electrode was 1.1 $\mu \mathrm{A} \mathrm{mM} \mathrm{m}^{-1} \mathrm{~cm}^{-2}$.

Figure 3 shows the calibration curve for the hydrogen peroxide sensor based enzyme electrode. A steady state

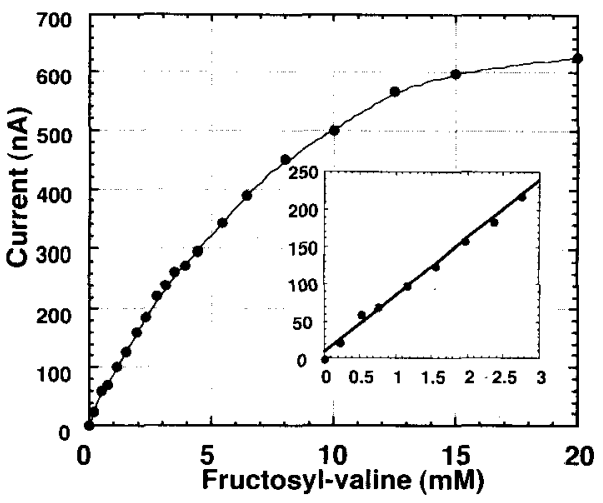

Fig. 2 Calibration curve for the mediator-type enzyme sensor using carbon paste electrode. Inset graph is an enlargement of low fructosyl-valine concentration regions.

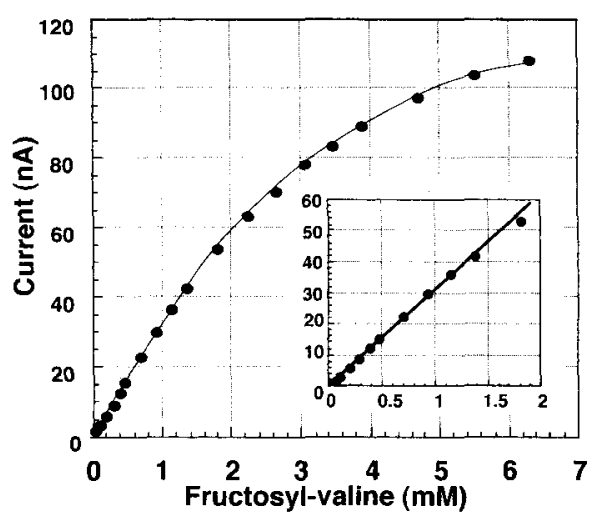

Fig. 3 Calibration curve for the hydrogen peroxide sensor based enzyme electrode. Inset graph is an enlargement of low fructosyl-valine concentration regions.

current at $600 \mathrm{mV}$ vs. $\mathrm{Ag} / \mathrm{AgCl}$ due to the hydrogen peroxide liberated by enzyme reaction attained within 4 minutes after each addition of fructosyl-valine. The calibration curve shows the linear correlation from $0.05 \mathrm{mM}$ to $1.8 \mathrm{mM}$ of fructosyl valine. The sensitivity of the electrode was $0.42 \mu \mathrm{A} \mathrm{mM} \mathrm{m}^{-1} \mathrm{~cm}^{-2}$, much better than the case of mediator-type enzyme sensor using carbon paste enzyme electrode. A bare Pt electrode had no response to addition of fructosyl-valine.

The sensor responses of both systems took more than several minutes to obtain the steady state current. These were mainly due to the insufficient amount of enzyme on the electrode and also the immobilization methods employed in this study. The authors are currently investigating the method for sufficient preparation of FAO from marine yeast cell, consequently enables us the optimization of the quantity of FAO on the electrode for the rapid and sensitive sensor response.

Considering that physiological $\mathrm{HbA} 1 \mathrm{c}$ in blood is $4 \%$ to $15 \%$ of total hemoglobin $\left(8-20 \mathrm{~g} \cdot \mathrm{dL}^{-1}\right)$ in blood, $\left.{ }^{8}\right)$ fructosyl-valine concentration in blood is estimated to 0 . $05 \mathrm{mM}$ at a minimum level and $0.5 \mathrm{mM}$ at a maximum level. These results indicated that the potential of the application of novel FAO for enzyme sensor development. At the moment, hydrogen peroxide electrode based enzyme sensor showed higher sensitivity, however, the 
principle itself may suffer from the high potential for the sensor operation. The application of FAO for mediator type enzyme sensor system could be operated at lower potential than hydrogen peroxide electrode. However, there is another inherent problem that fructosyl-valine is spontaneously oxidized by the presence of mediator at the alkaline condition. ${ }^{16)}$ Therefore, further optimization in the operational condition as well as sensor construction are essential in order to develop an indeal FAO based enzyme senor for HbAlc diagnosis.

\section{References}

1) The diabetes control and complications trial research group, New Engl. J. Med., 329, 968 (1993).

2) J. Landenson, K. Chan, and P. Kilzer, Clin. Chem., 31, 1060 (1985).

3) E. John and E. Carl, J. Am. Chem. Soc., 75, 316 (1953).

4) D. Goldstein, K. Parker, and J. England, Diabetes, 31 suppl 3, 70 (1982).

5) D. Nathan, D. Singer, K. Hurxthal, and J. Goodson, $N$. Engl. J. Med., 310, 341 (1984).

6) S. Standing and R. Taylor, Ann. Clin. Biochem., 29, 494
(1992).

7) U. Stenman, K. Pesonen, K. Ylinen, M. Huhtala, and K. Teramo, J. Chromatogr., 297, 327 (1984).

8) D. Wilson, J. Bogacz J, C. Forsythe, P. Turk, T. Lane, R. Gates, and D. Brandt, Clin. Chem., 39, 2090 (1993).

9) N. Watanabe, M. Ohtsuka, S. Takahashi, Y. Sakano, and D. Fujimoto, Agric. Biol. Chem., 54, 1063 (1990).

10) T. Horiuchi and T. Kurokawa, Agric. Biol. Chem., 55, 333 (1991).

11) Y. Sakai, N. Yoshida, A. Isogai, Y. Tani, and N. Kato, Biosci. Biotech. Biochem., 59, 487 (1995).

12) N. Yoshida, Y. Sakai, M. Serata, Y. Tani, and N. Kato, Appli. Environ. Microbiol., 61, 4487 (1995).

13) M. Takahashi, P. Monika, and M. Vincent, J. Biol. Chem., 272, 3437 (1997).

14) T. Horiuchi, T. Kurokawa, and N. Saito, Agric. Biol. Chem., 53, 103 (1989).

15) K. Sode, F. Ishimura, and W. Tsugawa, Marine Biotechnol., in press.

16) R. N. Johnson, P. A. Metcalf, and J. R. Baker, Clin. Chim. Acta, 127, 87 (1983). 